\title{
PENGARUH MODEL PEMBELAJARAN KOOPERATIF DENGAN METODE TALKING STICK BERBANTUAN QUESTION CARD TERHADAP AKTIVITAS BELAJAR IPS SISWA KELAS VIII DI SMP NEGERI 7 SINGARAJA
}

\author{
Luh Risfa Diantini $^{1}$, Lulup Endah Tripalupi² ${ }^{2}$, Kadek Rai Suwena ${ }^{3}$ \\ Program Studi Pendidikan Ekonomi \\ Universitas Pendidikan Ganesha \\ Singaraja, Indonesia
}
e-mail: diantinirisfa@gmail.com¹, lulup tripalupi@yahoo.com² kadeksuwena@yahoo.co.id ${ }^{3}$

\begin{abstract}
Abstrak
Penelitian ini bertujuan untuk mengetahui pengaruh penggunaan model pembelajaran kooperatif dengan metode talking stick berbantuan question card dan tidak menggunakan model pembelajaran kooperatif dengan metode talking stick berbantuan question card terhadap aktivitas belajar IPS siswa kelas VIII di SMP Negeri 7 Singaraja. Penelitian ini merupakan penelitian eksperimen semu dengan rancangan Post-Test Only Control Group Desain. Subjek penelitian adalah siswa kelas VIII D dan kelas VIII E. Objek penelitian adalah aktivitas belajar siswa dan model pembelajaran kooperatif dengan metode talking stick berbantuan question card. Data dikumpulkan menggunakan lembar observasi. Data dianalisis menggunakan analisis uji-t. Hasil penelitian menunjukkan, bahwa ada pengaruh penggunaan model pembelajaran kooperatif dengan metode talking stick berbantuan question card dan tidak menggunakan model pembelajaran kooperatif dengan metode talking stick berbantuan question card terhadap aktivitas belajar IPS siswa kelas VIII di SMP Negeri 7 Singaraja. Hasil analisis uji-t menunjukkan nilai t sebesar 3,830 dengan nilai signifikansi sebesar $0,000<0,05$, sehingga $\mathrm{H}_{\mathrm{a}}$ diterima dan $\mathrm{H}_{0}$ ditolak.
\end{abstract}

Kata kunci: model pembelajaran kooperatif, metode talking stick, media question card, aktivitas belajar.

\begin{abstract}
This study aims to determine the effect of using cooperative learning model of talking stick method assisted by question card and were not using cooperative learning model of talking stick method assisted by question card to the social studies learning activities of grade VIII students in SMP Negeri 7 Singaraja. This research was a quasiexperimental study of the Post-Test Only Control Group Desaign. The Subjects of this study were class VIII D and class VIII E. The objects in this study are student learning activities and cooperative learning model of talking stick method assisted by question card. The data were collected using an observation sheet. The data analyzed by using t-test analysis. The results showed that there were an effect of using cooperative learning model of talking stick method assisted by question card and were not using cooperative learning model of talking stick method assisted by question card to the social studies learning activities of grade VIII students in SMP Negeri 7 Singaraja. The result of t-test the score of $\mathrm{t} 3,830$ with the significant value of $0,000<0,05$, so $\mathrm{Ha}_{\mathrm{a}}$ could be accepted and $\mathrm{H}_{0}$ was rejected.
\end{abstract}

Keywords: cooperative learning model, talking stick method, media question card, learning activities. 


\section{PENDAHULUAN}

Salah satu faktor yang mempengaruhi keberhasilan proses pembelajaran adalah ketepatan dalam pemilihan model pembelajaran sesuai dengan tujuan dan materi yang akan diterapkan. Setiap model pembelajaran memiliki kelebihan dan kelemahan. Banyak model pembelajaran yang dapat digunakan oleh guru dalam melaksanakan kegiatan proses belajar mengajar. Salah satu model pembelajaran yang dapat digunakan adalah model pembelajaran kooperatif dengan metode talking stick. Model pembelajaran kooperatif adalah model pembelajaran yang berfokus pada penggunaan kelompok kecil siswa untuk bekerjasama dalam memaksimalkan kondisi belajar untuk mencapai tujuan belajar (Sugiyanto, 2010). Dibentuknya kelompok bertujuan untuk memberikan kesempatan kepada seluruh siswa agar dapat terlibat secara aktif dalam proses pembelajaran dan dapat meningkatkan kemampuan siswa dalam mengerjakan tugas. Di dalam kelompok tugas anggota kelompok yaitu untuk mencapai ketuntasan dalam mengikuti pembelajaran dan saling membantu antar teman satu kelompok.

Dalam model pembelajaran kooperatif salah satu metode yang dapat dipergunakan adalah metode pembelajaran talking stick. Menurut Shoimin (2016:197) "talking stick (tongkat berbicara) adalah metode yang pada mulanya digunakan oleh penduduk asli Amerika untuk mengajak semua orang berbicara atau menyampaikan pendapat dalam suatu forum (pertemuan antarsuku)". Selain itu menurut Kurniasih \& Sani (2016) metode talking stick merupakan satu dari sekian banyak model pembelajaran kooperatif. Talking stick adalah suatu metode pembelajaran yang dilakukan dengan bantuan tongkat. Tongkat ini akan dijadikan sebagai jatah atau giliran untuk berpendapat atau menjawab pertanyaan dari guru setelah siswa mempelajari materi pelajaran (Kurniasih \& Sani 2016). Sedangkan Suprijono (2015) menyatakan bahwa talking stick adalah metode pembelajaran yang mendorong siswa untuk berani dalam mengemukakan pendapat. Sehingga, model pembelajaran kooperatif dengan metode talking stick merupakan suatu model pembelajaran yang dilakukan secara berkelompok, dimana siswa dilatih untuk berani menyampaikan pendapat, dan menjadikan siswa aktif dalam kegiatan belajar serta dapat menciptakan suasana kelas yang menyenangkan, yang dalam pelaksanaanya menggunakan bantuan tongkat dan diiringi dengan lagu. Tongkat digunakan sebagai tanda seseorang mempunyai hak suara (berbicara) yang diberikan secara bergiliran atau bergantian.

Setiap model pembelajaran pasti memiliki kelebihan, demikian pula model pembelajaran kooperatif dengan metode talking stick. Menurut Kurniasih \& Sani (2016) menyatakan bahwa kelebihan metode talking stick adalah menguji kesiapan siswa, melatih membaca dan memahami dengan cepat materi yang telah disampaikan, agar siswa lebih giat belajar karena siswa tidak pernah mengetahui tongkat akan sampai pada gilirannya. Sedangkan menurut Suprijono (2009) kelebihan dari metode talking stick adalah menguji kesiapan siswa, melatih membaca dan memahami materi dengan cepat, memacu siswa agar lebih giat belajar, siswa berani dalam mengemukakan pendapat.

Dalam proses belajar mengajar, peran media pembelajaran sangat diperlukan karena digunakan untuk menyampaikan pesan pembelajaran dari guru kepada siswa. Penggunaan media dalam pembelajaran dapat mempermudah siswa dalam memahami sesuatu yang abstrak menjadi lebih konkret. Sarana penunjang yang digunakan berupa media pembelajaran. Menurut Arsyad (2013:10) "media pembelajaran adalah segala sesuatu yang dapat digunakan untuk menyampaikan pesan atau informasi dalam proses belajar mengajar sehingga dapat merangsang perhatian dan minat siswa dalam belajar". Sedangkan menurut Mudlofir \& Rusydiyah (2016:122) "media pembelajaran adalah teknologi pembawa pesan yang dapat dimanfaatkan untuk keperluan pembelajaran".

Untuk melaksanakan metode pembelajaran talking stick, maka dapat dibantu dengan media pembelajaran berupa question card. Menurut Harjanto (dalam Ardani 2014) Question card atau kartu soal merupakan media visual yang 
berupa kertas berukuran $10 \times 10 \mathrm{~cm}$. Kartu ini berisi soal-soal tentang materi yang akan diajarkan. Menurut Mudlofir \& Rusydiyah (2016) menyatakan bahwa media pembelajaran ini memiliki beberapa manfaat dalam proses pembelajaran yaitu sebagai berikut. Pertama, mengarahkan perhatian siswa untuk berkonsentrasi kepada materi pelajaran. Kedua, pembelajaran akan lebih menarik perhatian siswa sehingga dapat menumbuhkan motivasi siswa. Ketiga, metode mengajar akan lebih bervariasi, sehingga siswa tidak bosan dan guru tidak kehabisan tenaga apabila mengajar untuk setiap jam pelajaran. Keempat, bahan pelajaran akan lebih jelas maknanya sehingga dapat dipahami oleh para siswa, dan memungkinkan siswa lebih menguasai tujuan pembelajaran.

Media pembelajaran selain memiliki beberapa manfaat dalam proses pembelajaran. Media pembelajaran juga memiliki beberapa fungsi. Menurut Arsyad (2013:15) "salah satu fungsi utama media pembelajaran adalah sebagai alat bantu mengajar yang turut mempengaruhi iklim, kondisi, dan lingkungan belajar yang ditata dan diciptakan oleh guru". Sedangkan menurut Sanjaya (2006) media pembelajaran mempunyai beberapa fungsi yaitu menangkap suatu objek atau peristiwa-peristiwa tertentu, memanipulasi keadaan, peristiwa, atau objek tertentu, menambah gairah dan motivasi belajar siswa.

Aktivitas belajar merupakan kegiatan atau perilaku yang terjadi selama proses belajar mengajar. Kegiatan-kegiatan yang di maksud adalah kegiatan yang mengarah pada proses belajar seperti bertanya, mengajukan pendapat, mengerjakan tugastugas, dapat menjawab pertanyaan guru dan bisa bekerjasama dengan siswa lain, serta tanggung jawab terhadap tugas yang diberikan. Menurut Sardiman (2016:96) "aktivitas belajar merupakan prinsip atau asas yang sangat penting di dalam interaksi belajar mengajar". Menurut Sudjana (2004:18) "aktivitas belajar adalah peristiwa yang siswanya terlibat langsung secara intelektual dan emosional sehingga siswa betul-betul berperan dan berpartisipasi aktif dalam suatu kegiatan yang dilakukan selama proses belajar mengajar berlangsung". Selanjutnya Paul B. Diedrich (dalam Sardiman, 2016) menyatakan bahwa aktivitas belajar digolongkan ke dalam 8 (delapan) kegiatan adalah visual activities, oral activities, listening activities, writing activities, drawing activities, motor activities, mental activities, dan emotional activities.

Salah satu mata pelajaran yang terdapat pada jenjang Sekolah Menengah Pertama (SMP) adalah ilmu pengetahuan sosial. IImu pengetahuan sosial mengajarkan kepada setiap siswa untuk berani berinteraksi antara manusia satu dengan manusia yang lainnya. Di dalam pendidikan IPS juga mempelajari wawasan pengetahuan yang cukup luas, sehingga siswa mampu hidup bersama dengan masyarakat sekitar. Menurut Trianto (2012:171) "Ilmu Pengetahuan Sosial (IPS) merupakan integrasi dari berbagai cabang ilmu-ilmu sosial, seperti sosiologi, sejarah, geografi, ekonomi, politik, hukum dan budaya". Sedangkan Solihatin \& Raharjo (2012) menyatakan bahwa ilmu pengetahuan sosial juga membahas hubungan antara manusia dengan lingkungannya. Lingkungan masyarakat dimana anak didik tumbuh dan berkembang sebagai bagian dari masyarakat, dihadapkan pada berbagai permasalahan yang ada dan terjadi di lingkungan sekitarnya.

Dalam dunia pendidikan, setiap bidang studi yang tercantum dalam kurikulum, pastinya memiliki tujuan yang harus dicapai dalam melaksanakan pembelajaran, begitu pula dengan mata pelajaran IPS. Menurut Trianto (2012:176) "tujuan utama ilmu pengetahuan sosial adalah untuk mengembangkan potensi peserta didik agar peka terhadap masalah sosial yang terjadi di masyarakat, memiliki sikap mental positif terhadap perbaikan segala ketimpangan yang terjadi, dan terampil mengatasi setiap masalah yang terjadi sehari-hari, baik yang menimpa dirinya sendiri maupun yang menimpa masyarakat". Sedangkan Solihatin \& Raharjo (2012:15) menyatakan bahwa "tujuan dari pendidikan IPS adalah untuk mendidik dan memberi bekal kemampuan dasar kepada siswa untuk 
mengembangkan diri sesuai dengan bakat, minat, kemampuan dan lingkungannya, serta bekal bagi siswa untuk melanjutkan pendidikan ke jenjang yang lebih tinggi".

Berdasarkan hasil pengamatan pada kelas VIII D dan VIII E SMP Negeri 7 Singaraja, bahwa guru sudah menggunakan metode diskusi dalam mengajar, namun saat siswa melakukan diskusi kelompok guru tidak memberikan bimbingan secara optimal, sehingga ditemukan masih ada siswa yang kurang aktif dalam mengikuti proses pembelajaran. Kurang aktifnya siswa, terlihat ketika siswa mengerjakan tugas secara berkelompok, hanya sebagian siswa yang serius dalam mengerjakannya. Demikian pula saat guru menjelaskan materi pembelajaran, beberapa siswa tidak memperhatikan, sehingga saat guru memberikan pertanyaan terkait materi yang sudah diberikan hanya 3-4 orang siswa yang mampu menjawabnya. Hasil wawancara yang dilakukan kepada guru mata pelajaran IPS di SMP Negeri 7 Singaraja, menyatakan bahwa kurang aktifnya siswa disebabkan, karena kurangnya media pembelajaran yang digunakan pada saat proses pembelajaran, dan model pembelajaran diskusi yang digunakan kurang bervariasi. Sedangkan menurut siswa, mereka tidak aktif karena kurang pahamnya siswa terhadap materi yang diberikan, sehingga siswa tidak tahu apa yang akan ditanyakan, dan siswa kurang berani dalam menyampaikan pendapat, karena takut salah.

Berdasarkan permasalahan tersebut, dapat disimpulkan kurang aktifnya siswa dalam proses pembelajaran, disebabkan karena strategi pembelajaran yang dipilih guru tidak sesuai dengan karakter siswa. Oleh karena itu, diperlukan suatu model pembelajaran yang lebih menarik dan menyenangkan serta dapat membuat siswa lebih aktif berinteraksi.

\section{METODE}

Penelitian ini merupakan penelitian eksperimen semu (Quasi Experiment). Rancangan yang digunakan dalam penelitian ini adalah "Post-test Only Control Group Design". Rancangan ini menggunakan dua kelompok yaitu kelompok eksperimen dan kelompok kontrol. Kelompok eksperimen adalah kelompok yang akan diberikan perlakuan menggunakan model pembelajaran kooperatif dengan metode talking stick berbantuan question card. Sedangkan kelompok kontrol adalah kelompok yang tidak diberikan perlakuan model pembelajaran kooperatif dengan metode talking stick berbantuan question card. Di akhir penelitian, kedua kelompok akan diberikan perlakuan yang sama. Penelitian ini dilaksanakan di SMP Negeri 7 Singaraja yang berlokasi di Desa Alasangker, Kecamatan Buleleng, Kabupaten Buleleng, Provinsi Bali.

Prosedur penelitian yang dilakukan pada penelitian ini meliputi beberapa tahapan yaitu sebagai berikut. Pertama, tahap persiapan. Kegiatan yang dilakukan pada tahap persiapan yaitu meminta ijin kepada kepala sekolah SMP Negeri 7 Singaraja untuk melakukan penelitian disekolah dan melaksanakan observasi awal untuk melihat kondisi di lapangan. Kedua, tahap pelaksanaan. Pada saat melaksanakan eksperimen, pertemuan akan diadakan sebanyak tiga kali pertemuan yaitu memberikan perlakuan model pembelajaran kooperatif dengan metode talking stick berbantuan question card pada kelas eksperimen dan tidak memberikan perlakuan model pembelajaran kooperatif dengan metode talking stick berbantuan question card pada kelas kontrol, sekaligus mengumpulkan data mengenai aktivitas belajar siswa. Ketiga, tahap akhir. Kegiatan yang dilakukan pada tahap akhir yaitu mengolah dan menganalisis data aktivitas belajar dengan menggunakan uji prasyarat yaitu uji normalitas dan homogenitas. Setelah melakukan uji prasyarat, langkah selanjutnya akan dilakukan uji-t. Tahap selanjutnya membuat kesimpulan dan menyusun laporan penelitian.

Subjek dalam penelitian ini adalah siswa kelas VIII D sebagai kelas eksperimen yang berjumlah 31 orang yang terdiri dari 18 orang laki-laki dan 13 orang perempuan dan kelas VIII E sebagai kelas kontrol yang berjumlah 29 orang yang terdiri dari 17 orang laki-laki dan 12 orang perempuan. Sedangkan objek dalam 
penelitian ini adalah aktivitas belajar siswa dan model pembelajaran kooperatif dengan metode talking stick berbantuan question card.

Jenis data yang digunakan dalam penelitian ini adalah data kuantitatif. Menurut Sugiyono (2008:7) "data kuantitatif yaitu data yang berupa angka-angka". Data kuantitatif diperoleh dari lembar observasi aktivitas belajar pada mata pelajaran IPS yang diberikan kepada siswa mengenai penggunaan suatu model pembelajaran kooperatif dengan metode talking stick berbantuan question card. Sumber data yang digunakan dalam penelitian ini adalah data primer dan data sekunder. Data primer berupa data aktivitas belajar siswa. Sedangkan data sekunder berupa nama siswa kelas VIII SMP Negeri 7 Singaraja tahun ajaran 2018/2019.

Penelitian ini melibatkan dua jenis variabel yaitu variabel bebas (independent variable) dan variabel terikat (dependent variable). Variabel bebas dalam penelitian ini adalah pembelajaran menggunakan model kooperatif dengan metode talking stick. Sedangkan variabel terikat dalam penelitian ini adalah aktivitas belajar siswa.

Dalam penelitian ini, definisi operasional variabel melibatkan dua jenis variabel yaitu variabel bebas dan variabel terikat. Kedua variabel tersebut akan dijelaskan sebagai berikut. Pertama, model pembelajaran kooperatif dengan metode talking stick merupakan suatu model pembelajaran yang dilakukan secara berkelompok, dimana siswa dilatih untuk berani menyampaikan pendapat dan menjadikan siswa aktif dalam kegiatan belajar serta dapat menciptakan suasana kelas yang menyenangkan, yang dalam pelaksanaannya menggunakan bantuan tongkat dan diiringi dengan lagu. Tongkat digunakan sebagai tanda seseorang mempunyai hak suara (berbicara) yang diberikan secara bergiliran atau bergantian. Kedua, aktivitas belajar adalah peristiwa interaksi belajar mengajar yang siswanya terlibat secara intelektual dan emosional serta memberikan kesempatan belajar sendiri kepada siswa.

Adapun metode pengumpulan data yang digunakan dalam penelitian ini adalah observasi dan dokumentasi. Metode observasi ini digunakan untuk mengumpulkan data mengenai aktivitas belajar siswa dalam proses pembelajaran di kelas. Alat pengumpulan datanya berupa lembar observasi aktivitas belajar siswa. Metode dokumentasi ini digunakan untuk mengumpulkan data berupa jumlah siswa dan nama siswa kelas VIII D dan kelas VIII E.

Instrumen penelitian sangat erat kaitannya dengan teknik pengumpulan data. Menurut Arikunto (2006) instrumen penelitian adalah alat yang digunakan oleh peneliti untuk mengumpulkan data. Data aktivitas belajar dikumpulkan menggunakan lembar observasi aktivitas belajar siswa. Dengan cara mengamati secara langsung kegiatan yang dilakukan siswa saat proses pembelajaran. Dalam lembar observasi penilaian aktivitas belajar siswa yang terdiri atas empat indikator aktivitas yang masingmasing memiliki lima deskriptor penilaian. Adapun indikator yang dinilai dalam lembar observasi aktivitas belajar siswa yaitu visual activities, oral activities, mental activities dan emosional activities. Data aktivitas belajar siswa secara individu dianalisis berdasarkan persentase kemunculan tiap deskriptor pada tiap-tiap indikator aktivitas belajar selama proses pembelajaran berlangsung.

Metode analisis data yang digunakan dalam penelitian ini adalah uji-t. Sebelum dilakukan pengujian hipotesis untuk mendapatkan simpulan, maka akan dilakukan uji prasyarat. Uji prasyarat yang dilakukan adalah uji normalitas dan homogenitas. Uji normalitas digunakan untuk mengetahui apakah data tersebut berdistribusi normal atau tidak. Data dikatakan berdistribusi normal apabila taraf signifikansi yang diperoleh > 5\%. Uji normalitas dapat dilakukan dengan menggunakan bantuan dari program SPSS (Statistical Program Social Science) versi 16.0 for Windows. Sedangkan uji homogenitas digunakan untuk memperoleh data empiris bahwa perbedaan yang terjadi pada uji hipotesis benar-benar terjadi akibat adanya perbedaan antar kelompok. Data dikatakan homogen apabila taraf signifikansi yang diperoleh > 5\%. Uji homogenitas varian dapat dilakukan dengan menggunakan bantuan dari 
program SPSS (Statistical Program Social Science) versi 16.0 for Windows.

Setelah data dikatakan berdistribusi normal dan memiliki varian yang sama, maka uji hipotesis dapat dilakukan dengan menggunakan uji-t. Uji-t dilakukan dalam penelitian ini, karena untuk membandingkan satu variabel bebas dan satu variabel terikat. Uji-t digunakan untuk menguji koefisien regresi secara parsial atau dapat digunakan untuk mengetahui pengaruh dari masing-masing variabel. Uji-t dilakukan dengan menggunakan bantuan dari program SPSS versi 16.0 for Windows. Dengan kriteria pengujian, jika taraf signifikansi $<5 \%$ maka $H_{a}$ diterima dan sebaliknya jika taraf signifikansi $>5 \%$, maka $H_{a}$ ditolak.

\section{HASIL DAN PEMBAHASAN \\ Hasil Penelitian}

Berdasarkan data hasil penelitian mengenai model pembelajaran kooperatif dengan metode talking stick berbantuan question card terhadap aktivitas belajar IPS siswa kelas VIII di SMP Negeri 7 Singaraja yang diperoleh melalui lembar observasi aktivitas belajar siswa terhadap 60 orang siswa, yang terbagi dalam 2 (dua) kelompok yaitu kelompok ekperimen dan kontrol. Adapun rincian mengenai hasil penelitian terkait dengan model pembelajaran kooperatif dengan metode talking stick berbantuan question card terhadap aktivitas belajar IPS siswa kelas VIII di SMP Negeri 7 Singaraja dapat dilihat dari masing-masing tabel berikut.

Tabel 1. Data Aktivitas Belajar IPS Kelompok Eksperimen

\begin{tabular}{lccrr}
\hline Skor & $\begin{array}{c}\text { Jumlah } \\
\text { Siswa }\end{array}$ & & Persentase (\%) & Kategori \\
\cline { 4 - 5 } $79-99$ & 6 & 19 & Sangat Aktif \\
$66-78$ & 16 & 52 & Aktif \\
$53-65$ & 9 & 29 & Cukup Aktif \\
$40-52$ & 0 & 0 & Kurang Aktif \\
$20-39$ & 0 & 0 & Sangat Kurang Aktif \\
Total & $\mathbf{3 1}$ & $\mathbf{1 0 0}$ & \\
\hline
\end{tabular}

Berdasarkan data aktivitas belajar IPS kelompok eksperimen pada tabel 1 di atas dijelaskan bahwa siswa yang mendapat kategori sangat aktif sebanyak 6 orang, dengan persentase (19\%). Siswa yang mendapat kategori aktif sebanyak 16 orang,

dengan persentase (52\%) dan untuk siswa yang mendapat kategori cukup aktif sebanyak 9 orang, dengan persentase (29\%). Sedangkan untuk siswa yang medapat kategori kurang aktif dan sangat kurang aktif tidak ada (0\%).

Tabel 2. Data Aktivitas Belajar IPS Kelompok Kontrol

\begin{tabular}{|c|c|c|c|}
\hline Skor & $\begin{array}{c}\text { Jumlah } \\
\text { Siswa }\end{array}$ & Persentase (\%) & Kategori \\
\hline $79-99$ & $\frac{\text { Siswa }}{0}$ & 0 & Sangat Aktif \\
\hline $66-78$ & 7 & 24 & Aktif \\
\hline $53-65$ & 18 & 62 & Cukup Aktif \\
\hline $40-52$ & 4 & 14 & Kurang Aktif \\
\hline $20-39$ & 0 & 0 & Sangat Kurang Aktif \\
\hline Total & 29 & 100 & \\
\hline
\end{tabular}

Berdasarkan data aktivitas belajar IPS kelompok kontrol pada tabel 2 di atas dijelaskan bahwa siswa yang mendapat kategori sangat aktif tidak ada (0\%). Siswa yang mendapat kategori aktif sebanyak 7 orang, dengan persentase (24\%) dan untuk siswa yang mendapat kategori cukup aktif sebanyak 18 orang, dengan persentase $(62 \%)$. Sedangkan untuk siswa yang mendapat kategori kurang aktif sebanyak 4 orang, dengan persentase (14\%) dan untuk kategori sangat kurang aktif tidak ada $(0 \%)$.

Berdasarkan tabel 3 di bawah ini, diperoleh nilai t sebesar 3,830 dengan nilai 
signifikansi sebesar 0,000 $<0,05$, maka $\mathrm{H}_{\mathrm{a}}$ diterima dan $\mathrm{H}_{0}$ ditolak, dapat disimpulkan bahwa ada pengaruh penggunaan model pembelajaran kooperatif dengan metode talking stick berbantuan question card dan tidak menggunakan model pembelajaran kooperatif dengan metode talking stick berbantuan question card terhadap aktivitas belajar IPS siswa kelas VIII di SMP Negeri 7 Singaraja.

Tabel 3. Hasil Uji-t (Independent Samples Test)

Levene's

Test for

Equality of

Variances

t-test for Equality of Means

\begin{tabular}{|c|c|c|c|c|c|c|c|c|c|c|}
\hline & & \multirow[b]{2}{*}{$F$} & \multirow[b]{2}{*}{ Sig. } & \multirow[b]{2}{*}{$\mathrm{t}$} & \multirow[b]{2}{*}{ Df } & \multirow{2}{*}{$\begin{array}{l}\text { Sig. } \\
(2- \\
\text { tailed })\end{array}$} & \multirow{2}{*}{$\begin{array}{c}\text { Mean } \\
\text { Difference }\end{array}$} & \multirow{2}{*}{$\begin{array}{l}\text { Std. Error } \\
\text { Difference }\end{array}$} & \multicolumn{2}{|c|}{$\begin{array}{l}95 \% \text { Confidence } \\
\text { Interval of the } \\
\text { Difference }\end{array}$} \\
\hline & & & & & & & & & Lower & Upper \\
\hline \multirow[t]{2}{*}{$\begin{array}{l}\text { Aktivitas } \\
\text { Belajar } \\
\text { Siswa }\end{array}$} & $\begin{array}{l}\text { Equal } \\
\text { variances } \\
\text { assumed }\end{array}$ & 2.157 & .147 & 3.830 & 58 & .000 & 8.53843 & 2.22911 & 4.07638 & 13.00049 \\
\hline & $\begin{array}{l}\text { Equal } \\
\text { variances } \\
\text { not } \\
\text { assumed }\end{array}$ & & & 3.868 & 55.312 & .000 & 8.53843 & 2.20762 & 4.11481 & 12.96205 \\
\hline
\end{tabular}

(Sumber: Output SPSS versi 16.0 for Windows)

\section{Pembahasan}

Berdasarkan hasil penelitian di kelas

VIII SMP Negeri 7 Singaraja, setelah menerapkan model pembelajaran kooperatif dengan metode talking stick berbantuan question card pada kelas eksperimen, dapat mengatasi permasalahan yang terjadi diantaranya yaitu siswa menjadi lebih aktif dalam mengikuti proses pembelajaran, terlihat saat melakukan diskusi kelompok. Siswa aktif berdiskusi dengan kelompok untuk memecahkan permasalahan yang terdapat pada LKS, aktif dalam bertanya, aktif dalam menanggapi pertanyaan yang diberikan temannya saat diskusi, dan aktif dalam menyampaikan pendapat di depan kelas saat presentasi berlangsung.

Selain itu, saat melakukan metode talking stick berbantuan media question card siswa tampak senang dan bersemangat dalam mengikuti proses pembelajaran. Hal tersebut dikarenakan siswa lebih menyukai proses pembelajaran yang dilakukan sambil bermain, sehingga proses belajar mengajar yang dilaksanakan lebih menyenangkan dan tidak dirasakan membosankan bagi siswa. Oleh karena itu, dengan menerapkan metode talking stick berbantuan media question card dapat menjadikan siswa lebih antusias dalam mengikuti proses pembelajaran. Kemudian siswa menjadi lebih termotivasi dalam menjawab pertanyaan yang diberikan oleh guru terlihat saat melaksanakan metode talking stick dengan berbantuan media question card. Hal tersebut dikarenakan sebelum guru memberikan pertanyaan kepada siswa, terlebih dahulu siswa diajak untuk bermain tongkat sambil bernyanyi. Tongkat digunakan sebagai tanda seseorang untuk mempunyai hak suara (berbicara) yang diberikan secara bergiliran atau bergantian. Dimana lagu tersebut berhenti, disanalah tongkat akan berhenti pula. Siswa yang memegang tongkat terakhir, akan mendapat giliran untuk menjawab pertanyaan yang diberikan oleh guru. Pertanyaan itu akan disajikan dalam bentuk question card. Secara tidak langsung semua siswa akan mendapat giliran untuk menjawab pertanyaan. Sehingga dari hal itu, akan dapat memacu siswa untuk lebih giat dalam belajar.

Selanjutnya siswa lebih berani dalam mengemukakan pendapat. Hal tersebut 
terlihat saat melaksanakan metode talking stick berbantuan media question card, setiap siswa yang memegang tongkat saat lagunya berhenti, maka siswa tersebut harus sudah mempunyai kesiapan dalam menjawab pertanyaan yang akan diberikan oleh guru. Sehingga dengan menerapkan metode talking stick berbantuan media question card, siswa yang dulunya tidak berani menyampaikan berpendapat, maka akan berani untuk berpendapat. Dengan menerapkan model pembelajaran kooperatif dengan metode talking stick berbantuan question card akan dapat meminimalkan terjadinya monopoli kelas oleh siswa-siswa yang pintar, sehingga setiap siswa dipastikan telah belajar. Hasil penelitian di atas sejalan dengan pendapat Suprijono (2009) menyatakan bahwa kelebihan metode talking stick dapat menguji kesiapan siswa dalam membaca dan memahami materi dengan cepat, sehingga memacu siswa untuk lebih giat belajar dan berani dalam mengemukakan pendapat. Selain itu, diperkuat oleh pendapat Shoimin (2016) yang menyatakan bahwa metode pembelajaran ini akan menciptakan suasana kelas yang menyenangkan dan membuat peserta didik aktif dalam belajar.

Lebih lanjut penelitian ini didukung dengan hasil penelitian yang dilakukan oleh Astuti (2013) menunjukkan bahwa dengan menerapkan metode talking stick, siswa lebih mudah dalam memahami materi pelajaran dan siswa lebih senang dalam mengikuti pembelajaran. Selain itu, siswa terlihat lebih aktif serta tidak malu lagi dalam mengemukakan pendapat dan menjawab pertanyaan yang diberikan oleh guru. Hal tersebut dikarenakan siswa lebih menyukai kegiatan belajar yang dilakukan sambil bermain, sehingga proses belajar mengajar yang dilaksanakan dengan nuansa permainan akan sangat menyenangkan bagi siswa. Sama halnya penelitian yang dilakukan oleh Apriyanti Dewi (2017) menunjukkan bahwa dengan menerapkan model pembelajaran kooperatif tipe talking stick berbantuan media question card menjadikan proses pembelajaran lebih menyenangkan dan anak-anak lebih cepat untuk memahami materi yang diajarkan sehingga mampu membangkitkan semangat dan minat siswa untuk belajar.

Penelitian lain yang mendukung hasil penelitian ini dilakukan oleh Sari (2017) menunjukkan bahwa dengan menerapkan model pembelajaran kooperatif tipe talking stick peserta didik terlihat aktif dalam mengungkapkan pendapat, aktif dalam menjawab pertanyaan dan aktif dalam bertanya. Kemudian kelebihan yang lain yaitu membuat peserta didik lebih memahami materi sehingga pemahaman peserta didik dapat lebih meningkat, peserta didik sangat antusias mengikuti pembelajaran dalam artikata peserta didik memberikan tanggapan positif terhadap model pembelajaran kooperatif tipe talking stick.

Berdasarkan uraian di atas, terbukti bahwa ada pengaruh model pembelajaran kooperatif dengan metode talking stick berbantuan question card terhadap aktivitas belajar IPS siswa kelas VIII di SMP Negeri 7 Singaraja.

\section{SIMPULAN DAN SARAN Simpulan}

Berdasarkan hasil penelitian dan pembahasan, maka dapat disimpulkan yaitu sebagai berikut. Pertama, aktivitas belajar IPS siswa yang diajar menggunakan model pembelajaran kooperatif dengan metode talking stick berbantuan question card pada kelas eksperimen menunjukkan bahwa siswa terlihat lebih aktif dalam mengikuti proses pembelajaran seperti, aktif dalam bertanya, aktif dalam menanggapi pertanyaan, aktif dalam mengemukakan pendapat serta siswa terlihat lebih senang dan bersemangat dalam mengikuti proses pembelajaran. Selain itu, dengan menerapkan model pembelajaran kooperatif dengan metode talking stick berbantuan media question card dapat memacu siswa untuk lebih giat lagi dalam belajar. Hal ini dikarenakan siswa lebih menyukai poses pembelajaran yang dilakukan sambil bermain, sehingga proses belajar mengajar yang dilaksanakan lebih menyenangkan dan tidak dirasakan membosankan bagi siswa. Kedua, aktivitas belajar IPS siswa yang tidak diajar menggunakan model pembelajaran kooperatif dengan metode talking stick 
berbantuan question card pada kelas kontrol menunjukkan bahwa masih ada siswa yang kurang aktif dalam mengikuti proses pembelajaran seperti, kurang aktifnya siswa dalam bertanya, kurang aktif dalam menyampaikan pendapat dan kurang aktif dalam menjawab pertanyaan yang diberikan oleh guru. Hal ini dikarenakan metode diskusi yang dipilih tidak sesuai dengan karakter siswa sehingga siswa terlihat jenuh dalam belajar, maka saat proses diskusi berlangsung masih ada siswa yang tidak memperhatikan penjelasan dari temannya. Ketiga, ada pengaruh penggunaan model pembelajaran kooperatif dengan metode talking stick berbantuan question card dan tidak menggunakan model pembelajaran kooperatif dengan metode talking stick berbantuan question card terhadap aktivitas belajar IPS siswa kelas VIII di SMP Negeri 7 Singaraja. Dari hasil analisis uji-t dengan menggunakan program SPPS versi 16.0 for Windows menunjukkan bahwa nilai $\mathrm{t}$ sebesar 3,830 dengan nilai signifikansi yang diperoleh sebesar $0,000<0,05$, sehingga $\mathrm{H}_{\mathrm{a}}$ diterima dan $\mathrm{H}_{0}$ ditolak. Artinya model pembelajaran kooperatif dengan metode talking stick berbantuan question card memiliki pengaruh yang signifikan terhadap aktivitas belajar IPS pada siswa kelas VIII di SMP Negeri 7 Singaraja.

\section{Saran}

Adapun saran yang dapat disampaikan berdasarkan hasil penelitian yang telah dilakukan yaitu sebagai berikut. Pertama, siswa disarankan agar lebih berperan aktif dan proaktif dalam mencari sumber belajar lain sehingga siswa mampu berinteraksi dalam kegiatan belajar mengajar. Kedua, guru hendaknya dalam memberikan pembelajaran lebih bervariasi seperti, dalam memilih model pembelajaran dan metode pembelajaran yang digunakan sesuai dengan materi pelajaran dan karakteristik siswa. Ketiga, disarankan kepada sekolah agar dapat menggunakan hasil penelitian ini sebagai referensi untuk perbaikan kegiatan belajar mengajar di sekolah. Keempat, diharapkan penelitian ini dijadikan sebagai acuan dan bahan bacaan untuk peneliti lain yang berminat melaksanakan penelitian lebih lanjut tentang model pembelajaran kooperatif dengan metode talking stick berbantuan question card pada mata pelajaran IPS maupun mata pelajaran lainnya agar memperhatikan kendala yang dialami peneliti sebagai bahan pertimbangan untuk perbaikan dan penyempurnaan penelitian yang akan dilaksanakan.

\section{DAFTAR PUSTAKA}

Apriyanti Dewi, Ni Putu Dian. 2017. Pengaruh Model Kooperatif Talking Stick Berbantuan Question Card Terhadap Kompetensi Pengetahuan IPS Siswa Kelas IV. Jurnal Mimbar $P G S D$ Universitas Pendidikan Ganesha Vol. 5 No. 2.

Ardani, Ni Putu Mita. 2014. Pengaruh Model Kooperatif TGT Berbantuan Media Question Card Terhadap Hasil Belajar IPS Siswa Kelas V. Jurnal Mimbar PGSD Universitas Pendidikan Ganesha Vol. 2 No. 1.

Arikunto, Suharsimi. 2006. Prosedur Penelitian Suatu Pendekatan Praktik. Jakarta: PT. Rineka Cipta.

Arsyad, Azhar. 2013. Media Pembelajaran. Jakarta: Rajawali Pers.

Astuti, Ni Nym Triadi. 2013. Pengaruh Metode Talking Stick Terhadap Hasil Belajar PKn Siswa Kelas V SD Di Gugus Krisna Kecamatan Negara. Jurnal Mimbar PGSD Universitas Pendidikan Ganesha Vol. 1 No. 1.

Kurniasih, Imas \& Berlin Sani. 2016. Ragam Pengembangan Model Pembelajaran. Jakarta: Kata Pena.

Mudlofir, Ali \& Evi Fatimatur Rusydiyah. 2016. Desain Pembelajaran Inovatif. Jakarta: PT. Raja Grafindo Persada.

Sanjaya, Wina. 2006. Strategi Pembelajaran Berorientasi Standar Proses Pendidikan. Jakarta: Kencana Prenada Media Group.

Sardiman. 2016. Interaksi \& Motivasi Belajar Mengajar. Jakarta: PT. Raja Grafindo Persada.

Sari, Linda. 2017. Pengaruh Model Pembelajaran Kooperatif Tipe Talking 
Stick Terhadap Aktivitas Belajar IPA Kelas $V$ MIN 6 Bandar Lampung. Skripsi Universitas Islam Negeri.

Shoimin, Aris. 2016. 68 Model Pembelajaran Inovatif Dalam Kurikulum 2013. Yogyakarta: Ar-Ruzz Media.

Solihatin, Etin \& Raharjo. 2012. Cooperative Learning, Analisis Model Pembelajaran IPS. Jakarta: Bumi Aksara.

Sudjana, Nana. 2004. Penilaian Hasil Proses Belajar Mengajar. Bandung: PT. Remaja Rosdakarya Offset.

Sugiyanto. 2010.2 Model-Model Pembelajaran Inovatif. Surakarta: Yuma Pressindo.

Sugiyono. 2008. Metode Penelitian Kuantitatif, Kualitatif, Dan R\&D. Bandung: CV. Alfabeta.

Suprijono, Agus. 2009. Cooperative Learning Teori \& Aplikasi PAIKEM. Yogyakarta: Pustaka Belajar.

- 2015. Cooperative Learning Teori \& Aplikasi PAIKEM (Edisi Revisi). Yogyakarta: Pustaka Belajar.

Trianto. 2012. Model Pembelajaran Terpadu Konsep Strategi, Dan Implementasinya dalam Kurikulum Tingkat Satuan Pendidikan (KTSP). Jakarta: Bumi Aksara. 